\title{
Introduction: Identity, Culture, and the Performance Paradigm
}

\author{
Silvia Caporale-Bizzini \\ University of Alicante \\ caporale@ua.es \\ Lucia Esposito \\ University of Teramo \\ lesposito@unite.it \\ Alessandra Ruggiero \\ University of Teramo \\ aruggiero@unite.it
}

\section{Contemporary narratives of identity}

Contemporary narratives in English ${ }^{1}$ have been through a notable process of change during the last three decades. New voices have questioned and reinterpreted the cultural heritage of the past in increasingly complex historical and social settings. The study and understanding of cultural processes and their relation to the notion of subjectivity have been marked by a number of factors: the prevailing existence of postmodern theories and readings of cultural phenomena; the commodification of culture; the questioning of notions of History and Grand Narratives; and the consequent radical revisions of Western tradition. Authors have used textuality to stress how their identities materialize in a writing defined by characters and narrators that shift between opposites, accept paradox as creative inspiration and represent a world which is marked by complexity, intertextuality and the reinterpretation of foundational discourses that have their roots in psychoanalysis, Modernism, Marxism, biology or linguistics. 
The postmodernist standpoint of experimental writing, though embedded in Modernism, gave voice to multiple subjectivities that were claiming both their right to be seen, heard and read, and to project this new self-perception through innovative writing strategies. However, critics such as Lawrence Driscoll (2009) have recently questioned the centrality of postmodern subjectivities as a field force of literary inspiration and have criticized the proliferation of "class blind" texts and "the ideological notion of a 'classless' contemporary British literature and culture" (2009: 1). ${ }^{2}$ At the beginning of the twenty-first century, critics and artists were faced with a deeper thinking on identitary discursive practices, according to Nick Bentley:

The 'post' of postmodernism, in literary terms, therefore, served to establish a link with this experimental attitude towards writing, whilst at the same time signaling that the experiment itself had shifted due to the changed historical situation in which writers of the late twentieth century found themselves. (2010: 31)

The endless quest to answer the "Who am I?" question opens up new spaces for enquiry. On one side, the theoretical inheritance of post-structuralism taught us that the Foucauldian notion of "penser autrement" was the answer. However, on the other side, the epistemological pillars of the Western identitary project were shattered, and as a consequence its representation.

A reflection on where we stand is necessary and it is time to decide what has to be discarded from the cultural politics of postmodernism and what has to be preserved for the reinterpretation of, for example, concepts such as history, memory, authorship, autobiographical narration, the codification of spaces or a new understanding of the relationship between the subject and the collective. In this sense, contemporary AngloAmerican culture is a thought-provoking field of enquiry where the voices of writers that form this mosaic are representative of a society which is multicultural, hybrid and fluid in its interpretation.

Contemporary society draws a cultural landscape that questions the relationship of individuals with cityscapes, trauma, or the reinterpretation of the past to understand the present. The latter concept gives life to texts that aim to both understand the present and run away from it; these narratives delve into the understanding of ourselves as subjects and of our relationship with the past while attempting to respond to excessive materialism and individualism that boomed during Thatcherism in Great Britain and Reaganism in the United States. History is not interpreted in realistic nineteenth-century terms, but in a way that delves into the gaps of the Foucauldian discontinuous historical process silenced by traditional historical thought (cf. Bentley, 2010: 120).

The new historical novel reinterprets the past as well as personal and collective memory and, as Nick Bentley suggests, it focuses on spaces, real or imagined (2010: 128). The reflection on nineteenth century Britain, for example, gives voice to discourses that Victorianism had silenced and made invisible, and it unveils how "[t]he very notion of Britishness was a creation of nineteenth century" (Bradford, 2007: 93). As a consequence, spaces of hybridity are created,where the concept of Englishness is 
questioned and reinterpreted. Generally, it can be argued that at the beginning of the twenty-first century, literature breaks the dichotomy between realist narrative strategies $v s$ postmodern narratives strategies, and opens to a wider understanding of the use of textuality as an amalgam of different approaches, which in turn challenges the dominant definition of identity. In the last decades, textuality has addressed a complex reality which is represented, among other things, by the social perception of shifting geographical borders and discourses on hybridity and cultural translation. Writers have responded to these challenges by turning to narratives about history, the urban landscape and, following the events of the 9/11 or the 2005 London bombings, to narratives about trauma, or pathological subjects. According to critics such as Philip Tew (2003; 2007), Richard Lane and Rod Mengham (2003), the origin of the narrative of trauma and of the pathological subject, for example, takes place in this new and confused search for identitary redefinition and in its inherited epistemological ambiguity. Philip Tew indicates that:

[...] 'trauma-culture fiction explores obsessively individual identity and a sense of one's fractious personal history, often retrieving lost memories or addressing feelings of intense alienation that result from being oppressed by stereotypes and conventional social expectations. (2007: 192)

Following this same line of thought, Lane and Menghan point out that: "In a fuller sense, the pathological can be thought of in relation to the disordered state of the individual within society, often involving an intense sense of dislocation" (2003: 193). This standpoint is the intersection with other issues which embody the literary representation of contemporary anxieties. Cultural or geographical spaces, for example, become a further site for interrogation and the representation of spaces becomes the projection of contemporary worries such as a different interpretation of (trans)gendered identities, hybridity, marginalized subjects in unfriendly metropolises or the presence of the perverse. Within a contemporary fluid and fragmented cultural context, we argue that the critical concepts of 'performance' and 'performativity' have arguably contributed to this metamorphosing scenario concerning the aesthetics and politics of identity and culture.

\section{Performance, performativity, and cultural critique}

From the early sixties, the birth and flourishing of anti-representational and anticonventional experiments in theatre with happenings and performance art, as well as a focalized understanding of theatrical practice and process, or indeed, of theatre 'as' practice and process, has led to a broadening of the areas of enquiry in theatre studies. This has boosted the re-theorizing of performance as a concept which has given rise to performance studies as a distinct discipline (thanks fundamentally to the American scholar and theatre director Richard Schechner). However, the field of performance studies has been significantly widened by convergent linguistic, sociological, 
anthropological and philosophical investments in the discourses of performance and performativity, including: J. L. Austin's definition of performative speech 'acts' (1962); Erving Goffman's metaphorization of performance as the modality for 'the presentation of self in everyday life' (1959); Victor Turner's examination of ritual as social drama and drama as social ritual $(1969,1982)$; the postmodern ruminations on the citational quality of identity (Derrida, 1988); and Judith Butler's theorization of gender performativity $(1993,1997)$. Therefore, as Elin Diamond points out, "performance has floated free of theatre precincts, to describe an enormous range of cultural activity", from "popular entertainments" to "speech acts, folklore, political demonstrations, conference behavior, rituals, medical and religious healing, and aspects of everyday life" (1996: 2). As a result, performance has become such a dominant interdisciplinary trope that its proponents see it as a key paradigm in our culture and as the motif and substance of the postmodern turn.

The close ties with postmodernism have been variedly theorized and recognized. According to Diamond, "because it appears to cut across and renegotiate institutional boundaries, as well as those of race, gender, class, and national identity, performance has become a convenient concept for postmodernism" (1996: 2-3). In fact, as Philip Auslander reminds us, already in 1977 Michel Benamou, one of the editors of Performance in Postmodern Culture, identified performance as "the unifying mode of the postmodern." In Benamou's view, the main feature of postmodern culture is that in our 'society of the spectacle' (in Guy Debord's words), or 'dramatized' society (in Raymond Williams'words), everything performs: technologies, art, political and social developments and the media, which especially contributes to make everything performative, including power and knowledge. Auslander adds that even more so today:

The 'postmodern turn' in a variety of humanistic and social scientific disciplines amounts mainly to viewing those disciplines and their objects of study in performance terms. Scholars [...] have come to see their respective discourses as contingent rather than absolute; as engaged with specific audiences rather than autonomous; as existing primarily in a specific, time-bound context; and as characterized by particular processes rather than by the products they generate. (2004: 99)

A processual dimension is actually at the core of this multi- and inter-disciplinary emphasis upon performance. As Marvin Carlson puts it: "The rise of an interest in performance reflects a major shift in many cultural fields from the what of culture to the how, from the accumulation of social, cultural, psychological, political, or linguistic data to a consideration of how this material is created, valorized, and changed, to how it lives and operates within the culture, by actions" (1996: IX). Performance is intrinsically dynamic given its connection with the idea of actions and acts performed before an audience, be it metaphorical or real. This may be why the father of Performance Studies, Richard Schechner, chooses to use the verb 'to perform' (implicating a doing) when he converts the question 'What is performance?' into 'What is to perform?', and when he also provides his answer: 'In business, sports, and sex, 'to perform' is to do something up to a standard - to succeed, to excel. In the arts, 'to 
perform' is to put on a show, a play, a dance, a concert. In everyday life, 'to perform' is to show off, to go to the extremes, to underline an action for those who are watching" (2013: 28).

According to the aforementioned illustration of the term's use, 'performance' is clearly a core, disseminated concept in our times, but the editors of this collection of essays essentially agree with all those who point out that it is also a highly 'contested' concept, as it embraces diverse and concurrent meanings. Fabrizio Deriu (2012), following Jon McKenzie's delineation of the field (2001), thinks that the clearest and also the most controversial ambivalence of the term can be recognized in the antagonism between two main occurrences of performance in contemporary society: on the one side, it is a principle of measurement and evaluation of individuals' and machines' productivity according to organizational and technological standards (respectively in terms of 'efficiency' and 'effectiveness'); on the other side, it is a cultural and artistic practice imbued with transformational and oppositional values and with the power to enact a critique (what McKenzie calls its 'efficacy') against those very terms of efficiency and effectiveness. Due to the wideness of the scope, performance actually represents, in McKenzie's opinion, today's dominant formation of knowledge and power, or what is now known as the 'performance paradigm'.

Evidently, pluralism and diversity have shaped trends in the postmodern and postpostmodern way of embodying 'performance' as an inter-disciplinary method, analytical tool and object of study within the 'performance paradigm'. According to Janelle Reinelt, the "post-structural critique of the sign, of representation, and of the subject is the philosophical backdrop to performance theory's concern with performance processes and its deliberate rejection of totalized/completed meanings" (2002: 205). Thus, unstable, non-unified and processual cultures and identities are the arena and field of investigation of all humanistic disciplines converging around the concepts of performance and performativity. The concept of 'performativity', in particular, having fully emerged in the 1980s and 1990s with the explosion of 'theory', collects under its rubric the multiple and different ways in which identity, race or gender can be played out, whether as mere reiteration of acts within the interpellative constraints of society or, conversely, as willed participation (agency). According to this view, which mainly follows Butler's theorization, the faculty to resist the normativity of socially pre-scripted roles (constructed within and through culture), would be given by the performance of a liminal, parodic or transgressive act, which is capable of producing a variation, a slippage, and thus a plurality, inside or beyond the norm.

This liminal performance, endowed with a certain degree of 'efficacy', could also be seen as that in-between or interstitial site, or 'location', where access to cultural meanings and critique is allowed. As Jill Dolan points out:

Tropes that use 'performance' and 'location' to make claims about identity and politics have been proliferating recently in cultural and critical theory. [...] In feminist studies and activism, for one example, positionality is a strategy that locates one's personal and political investments and perspectives across an argument, a gesture toward placing oneself within a critique of objectivity, but at the same time stopping the spin of post- 
structuralist or postmodernist instabilities long enough to advance a politically effective action. (1993: 417)

In this light, a 'position', just like 'performance', could be viewed as "an unstable but effective point of departure", and its localization as an enticing and worthy challenge for both cultural and literary studies in the twenty-first century.

$* * *$

Some of the papers published in this issue of Alicante Journal of English Studies are a selection of the contributions delivered at the Seminar "Performing Culture, Performing Identity" at the ESSE Conference, Bogazici University in Istanbul in September 2012. Seminar participants were asked to focus on the issues raised by the definition of performance and performativity in relation to the politics of identity and culture in current cultural studies within the contemporary British context. However, more articles were selected and added while compiling this collection, their inclusion has forcefully widened our field of enquiry. These essays present different points of view in relation to performativity and culture, but they all aim to reflect on the composite and stimulating lanscape of contemporary Anglo-American literature and culture from an interdisciplinary perspective and within the theoretical framework of Performance Studies.

Fabrizio Deriu and Lucia Esposito respectively review and comment upon the birth and development of Performance Studies and the fruitful contaminations with Cultural and Literary Studies, providing an introductory historical and theoretical outline. Complexity, ambiguity and plurality are differently approached and analyzed in the articles authored by Maria Laudando, Elena Igartuburu, Giuseppe De Riso, Amaya Fernández, Alessandra Ruggiero, Laura De Michele and Serena Guarracino. These authors problematise the relation between writing, reading and performance whilst delving into the questioning of identitary parameters both in traditional and postmodern terms. From different standpoints, the notion of contemporary subjectivity is stripped and related to hybridity, perversion, spatiality, normativity, spectatorial engagement or the commodification of the (postmodern) author. Barry Mauer, Asunción Aragón, Giuseppina Botta and José Carregal widen the original field of investigation and analysis and apply the critical perspective of Performance Studies to both North American Cultural Studies, Canadian Studies and Irish Studies. Their contributions have enriched our original project and allow us to speak to a wider spectrum of readers.

\section{Notes}

1. Following Nick Bentley (2010: 1), by using the adjective contemporary, we refer to texts written between 1975 and 2013, so far.

2. Lawrence Driscoll focuses on British literature, but his point of view can be applied to most of Western literatures. 
3. The quotation refers to Michel Benamou (1977): "Presence and Play", in Michel Benamou and Charles Caramello, eds., Performance in Postmodern Culture. Madison, WI: Coda, 3.

\section{References}

Auslander, Philip (2004): "Postmodernism and Performance", in Steven Connor, ed., The Cambridge Companion to Postmodernism. Cambridge: Cambridge University Press, $97-115$

Austin, J. L. (1962): How to Do Things with Words. Oxford: Clarendon Press.

Bentley, Nick (2010): Contemporary British Fiction. Edinburgh: Edinburgh University Press.

Bradford, Richard (2007): The Novel. Contemporary British Fiction. Oxford: Blackwell Publishing.

Butler, Judith (1993): Bodies that Matter: On the Discursive Limits of 'Sex'. London and New York: Routledge.

(1997): Excitable Speech, a Politics of the Performative. New York and London: Routledge.

Carlson, Marvin (1996): Performance. A Critical Introduction. London and New York: Routledge.

Deriu, Fabrizio (2012): Performático. Roma: Bulzoni.

Derrida, Jacques (1988): 'Signature Event Context', in Id., Limited inc. Evanston, Illinois: Northwestern University Press, 1-23.

Diamond, Elin (1996): "Introduction", in Elin Diamond, ed., Performance and Cultural Politics. London and New York: Routledge.

Dolan, Jill (1993): "Geographies of Learning: Theatre Studies, Performance and the Performatives", Theatre Journal 45(4): 417-441.

Driscoll, Lawrence (2009): Evading Class in Contemporray British Literature. Basingstoke, New York: Palgrave MacMillan.

Goffman, Erving (1959): The Presentation of Self in Everyday Life. Garden City, NY: Doubleday.

Lane, Richard and Rod Mengham (2003): British Fiction Today. London: Continuum.

McKenzie, Jon (2001): Perform or Else: From Discipline to Performance. London and New York: Routledge.

Reinelt, Janelle (2002): "The Politics of Discourse: Performativity Meets Theatricality." Substance 31(2/3, Issue 98/99): 211-215.

Schechner, Richard (2013, third edition): Performance Studies. An Introduction. London and New York: Routledge.

Tew, Philip (2007): The Contemporary British Novel. London: Continuum.

Turner, Victor (1969): The Ritual Process. Structure and Anti-structure. Chicago: Aldine Publishing Company.

(1982): From Ritual to Theatre. The Human Seriousness of Play. New York: PAJ Publications. 